\begin{tabular}{|c|c|c|}
\hline \multirow{2}{*}{\multicolumn{2}{|c|}{$\begin{array}{ll}\text { DE } & \text { DE GRUYTER } \\
\text { OPEN }\end{array}$}} & ECONOMIC THEMES (2016) 54(2): 217-232 \\
\hline & & DOI 10.1515/ethemes-2016-0011 \\
\hline
\end{tabular}

\title{
EMPIRICAL EVALUATION OF THE FISCAL POSITION IN SERBIA
}

\author{
Jadranka Đurović-Todorović \\ University of Nis, Faculty of Economics, Republic of Serbia \\ $\bowtie$ jadranka.djurovic@eknfak.ni.ac.rs
}

Marija Vuković

Novi Sad Business School, Novi Sad

\vlahmari@uns.ns.ac.rs

UDC

336.02

(497.11)

Review

paper

\begin{abstract}
The paper evaluates the size of the cyclical and structural components of the fiscal deficit of the Republic of Serbia for the period from the first quarter of 2002 to the second quarter of 2014. The method of the European Central Bank was used, where it is assumed that cyclically sensitive elements of state are budget income tax, profit tax, value added tax on the value, excises, social security contributions and unemployment benefits. Elasticity of cyclically sensitive elements relative to their macroeconomic bases are estimated using the VEC model with error correction. The results suggest that automatic stabilizers generally played a more prominent role than consistent countercyclical discretionary fiscal policy, which means that the discretionary measures were late or were not well targeted.
\end{abstract}

Received: 26.01.2016. Accepted: Keywords: cyclic deficit, structural deficit, GDP.

18.05.2016.

\section{Introduction}

The relevance of topics reflected in the stability of the fiscal deficit in the Republic of Serbia, which ranged from $0.5 \%$ of GDP in 2000 to $7.6 \%$ of GDP in 2012 and representing the trigger, both internal as well as external imbalances. As indicators for the assessment of fiscal policy in the paper the cyclically adjusted to the deficit and the structural deficit are constituted. Cyclical deficit arises as a result of the changed revenue and expenditure, due to cyclical movements of the economy. Structural fiscal deficit is a negative budget balance (excess of expenditure over income) in the economy, which 
operates at the natural rate of unemployment due to revenue shortfalls in the amount planned (Todorović-Đurović \& Đorđević, 2010, p. 379). The cyclicallyadjusted fiscal deficit or "deficit debt stabilization" measures whether the current fiscal arrangements are sustainable over the long term. The structural deficit as an indicator of the sustainability of the fiscal policy indicates the extent to which budget outcomes are affected by macroeconomic trends, and the impact of fiscal policy on the economy (through the effect on demand and over relative prices and therefore on the allocation of resources). Conceptually, the structural fiscal balance is a superior basis for assessing fiscal position of a country and keeping fiscal policy in relation to the actual fiscal balance. As a indicator of fiscal policy, the structural deficit has two advantages. First, to clean the deficit of the effects of economic cycles, and is actually a better bet for the assessment of fiscal policy rather than the use of the actual deficit. Second, it is easy to stand out in debates and statements by policy makers. These two reasons explain its usefulness and its popularity (Carnot et al., 2011, p. 207). However, the assessment of the fiscal position of the country and the conduct of fiscal policy based on structural fiscal balance is faced with some methodological difficulties, which can provide fertile ground for political manipulation.

The tools of empirical analysis of fiscal policies are mainly developed and applied to the data of the developed countries. Countries in transition differ from developed countries in many aspects, such as the most important structure of the state budget. State budgets in developed countries are higher (as a share of GDP), on the expenditure side more spending on transfers and revenue side is a function of personal and social security. In countries in transition transfers are usually small and the largest part of public spending is spending on goods and services and public sector wages. On the revenue side, indirect taxes are often the largest component. This is certainly true, but there is no reason to believe that the methodology applied for OECD countries should not be applied in other countries. In essence, this methodology in different ways approached the problem of reverse causality in the assessment of the effects of fiscal policy. Conceptually, there is no reason why radically different methodologies or even ignoring the problem of reverse causality should be a better solution for countries in transition. The real question, however, is the availability of data. Countries in transition have a drastic worsening of fiscal data from developed countries and it cannot be an obstacle to empirical assessments (Perotti, 2007, p. 3).

The aim is to analyze the possible methodological approaches to assess the cyclically adjusted and structural fiscal deficit and that, on the basis of methodologies prevailing in the EU countries, to carry out an econometric estimation of their height and dynamics in the Republic of Serbia for the period 2007-2014 (first quarter ), based on quarterly macroeconomic data. 


\section{Construction of Cyclical Fiscal Deficit in Serbia}

For the purposes of assessing cyclically adjusted deficit in Serbia, the authors shall apply the access to the European Central Bank. The method estimates the cyclically adjusted deficit consists of several steps: (i) identification of the cyclical sensitive elements of public revenues and public expenditures and their macroeconomic bases and calculation of the value of the relevant macroeconomic bases using the filter; (ii) estimate the elasticity of cyclically sensitive elements of the budget in relation to the macroeconomic base using the model with error correction (error-correction model); (iii) calculating the fiscal deficit and the cyclical nature of fiscal policy assessment.

Table 1 Cyclically sensitive elements of the expenditures and their macroeconomic bases

\begin{tabular}{|c|c|c|c|}
\hline $\begin{array}{c}\text { Cyclically sensitive } \\
\text { elements of the budget } \\
\text { (in current price) }\end{array}$ & $\begin{array}{c}\text { Source of } \\
\text { data }\end{array}$ & $\begin{array}{c}\text { Macroeconomic } \\
\text { bases } \\
\text { (in current price) }\end{array}$ & Source of data \\
\hline Income tax & $\begin{array}{c}\text { Ministry of } \\
\text { Finance }\end{array}$ & Wages & $\begin{array}{c}\text { Statistical } \\
\text { Office }\end{array}$ \\
\hline Corporate tax & $\begin{array}{c}\text { Ministry of } \\
\text { Finance }\end{array}$ & $\begin{array}{c}\text { Gross operating } \\
\text { surplus (GOS) }\end{array}$ & $\begin{array}{c}\text { Statistical } \\
\text { Office }\end{array}$ \\
\hline VAT & $\begin{array}{c}\text { Ministry of } \\
\text { Finance }\end{array}$ & $\begin{array}{c}\text { Personal } \\
\text { consumption }\end{array}$ & $\begin{array}{c}\text { Statistical } \\
\text { Office }\end{array}$ \\
\hline $\begin{array}{c}\text { Excise } \\
\text { contributions }\end{array}$ & $\begin{array}{c}\text { Ministry of } \\
\text { Finance }\end{array}$ & $\begin{array}{c}\text { Personal } \\
\text { consumption }\end{array}$ & $\begin{array}{c}\text { Statistical } \\
\text { Office }\end{array}$ \\
\hline $\begin{array}{c}\text { Unemployment } \\
\text { benefits }\end{array}$ & $\begin{array}{c}\text { Ministry of } \\
\text { Finance }\end{array}$ & $\begin{array}{c}\text { Total sum of } \\
\text { wages }\end{array}$ & $\begin{array}{c}\text { Statistical } \\
\text { Office }\end{array}$ \\
\hline
\end{tabular}

Source: The authors have created tabular interpretation.

Identification cyclically sensitive elements of public revenue and expenditure and their macroeconomic bases are shown in Table 1. As a macroeconomic basis, income tax is taken to earnings. The time series comprises quarterly data on the total amount of salaries in the public sector. The total amount of wages is obtained by multiplying the number of employees with the average wage in the public sector, the private sector and the sector of active farmers. Income tax expense for macroeconomic base has a gross operating surplus. It is calculated as the difference between GDP at constant prices and the mass of paid salaries in constant prices. Macroeconomic basis, the VAT and excise are personal consumption, and social security contributions, total earnings were accrued. The elasticity of unemployment benefits as well as cyclically sensitive components of the budget are calculated in relation to the base number of the unemployed. 
Calculating the value of the relevant macroeconomic bases is carried out using a HP (Hodrick-Prescott) filter, which is in line with the case law of the European Central Bank. Hodrick-Prescott (HP) filter is a method that is widely used among macroeconomists to assess the long-term trend component of a series. The method is first used in the working document (issued in 1997) by the Hodrick-Prescott in which he analyzes the postwar American business cycle. Technically, the HP filter is double-sided linear filter that calculates the smoothed series by reducing the variance. The parameter $\lambda$ controls the smoothing of the series. In applying the HP filter statisticians recommend using the smoothing parameter $\lambda=100$ for annual data; $\lambda=1,600$ for quarterly data, and $\lambda=14,400$ for monthly data. At the same time, the European Central Bank for the purposes of calculating the structural fiscal deficit uses the value of the smoothing parameter $\lambda=30$ for annual data, which corresponds to the value of the parameter $\lambda=480$ for quarterly data. In the paper was applied smoothing parameter $\lambda=300$, which is consistent with the length of the business cycle of 4 years, which corresponds to the average length of the business cycle in the Republic of Serbia. According to the assertion of the author Fatas \& Mihov (2008), it is likely that low-income countries have a shorter and variable business cycle due to less developed financial markets and weak economic institutions.

The advantages of this method are simplicity and transparency of the application. However, it has significant shortcomings. First, the use of the HP filter is based on the assessment of the length of the typical business cycles in individual economies, but that choice is to a large extent arbitrary. In addition, the HP filter can not detect structural breaks in the series. Also, using this filter calculated trend values at the beginning and end of the time series is very close to the values of the original series.

The output gap is a measure of demand, which is defined as the difference between the level of GDP and its equilibrium level, ie. trend. The equilibrium level of GDP is the level that can be achieved with the existing workforce, capital and productivity without upward pressure on prices. In contrast to the trend that has defined long-term factors, the GDP gap is determined by shortterm factors such as salary trends, credit activity or character of monetary policy. A positive output gap means that inflationary pressures coming from the demand, and vice versa.

The growth of the GDP gap above trend in 2007 and a high positive output gap in 2008 clearly signaled that the economy was overheated due to high credit growth, real wage growth, and due to the high trade balance of payments deficit. Economic growth in this period was not long-term. In 2009, due to the decline in economic activity deepened the negative output gap that continued in 2010 and 2011. 
Figure 1 The gap in GDP in Serbia - HP approach, the period 2001- 2014 (first quarter)

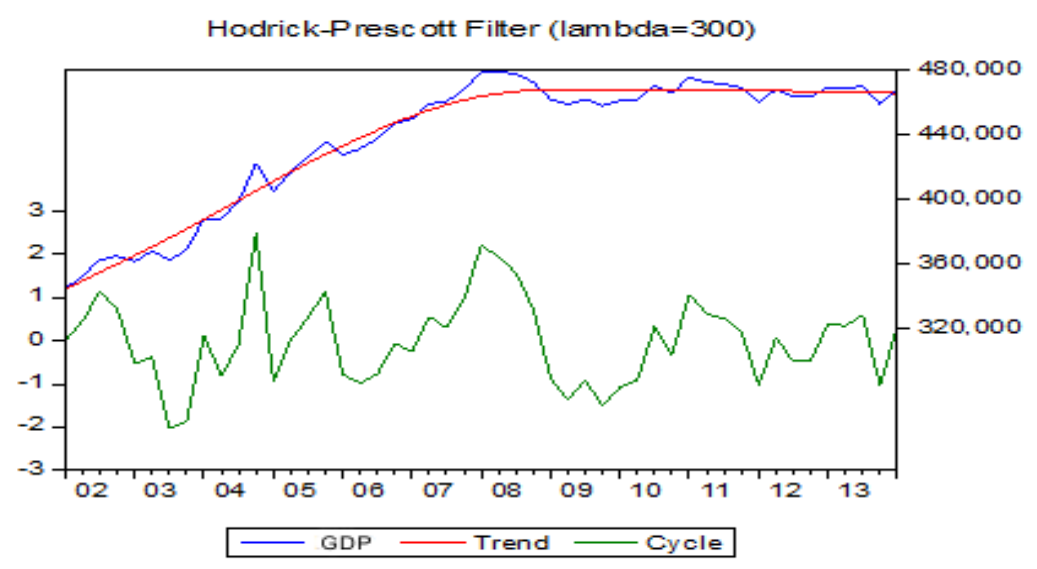

Source: For GDP data source is the Statistical Office of the Republic of Serbia. The calculation of the output gap were done by the authors.

Monetary policy has worked in the direction of an increase in inflation in early 2010, while, in contrast, seemed disinflationary negative GDP gap, culminating in the fourth quarter of 2013. Increased negative output gap in 2013 and 2014 is the result of the influence of many factors, but primarily to reduced investment in production capacity, difficulties in financing current production activities of the company and the negative tendencies in the labor market.

Figure 2 shows the percentage deviation of the actual value trend macroeconomic bases. It is evident that in the Republic of Serbia different macroeconomic bases oscillate in different phases of the business cycle. Access to the European Central Bank, takes this fact into account. Figure 2 shows that in the period of high demand (positive output gap), the unemployment rate was above trend, especially in the period 2004- 2006, and the rest period ranged below its trend. The wage bill was depressed compared to the trend in the period 2010-2011, which indicates that the fiscal policy of the Republic of Serbia was explicitly restrictive (reduction of public sector wages). Private consumption fluctuated around a trend, but in 2004 and the first quarter of 2007 to the fourth quarter of 2008 was above trend (high credit growth), which in turn suggests that the monetary policy of the Republic of Serbia was expansive (down real interest rates). Deviation base gross operating surplus above trend in the Republic of Serbia was explicitly in the period 2006-2008 (high economic growth and real wage growth), and the deviation below trend during the period 2010- 2011 (due to reduced investment in production capacity and the difficulty of financing the current production activities of the company. 
Figure 2 Deviation from the baseline macroeconomic trend and the GDP gap, the period 2002 to 2014 year (first quarter)

a) The deviation from the trend of unemployent and the GDP gap

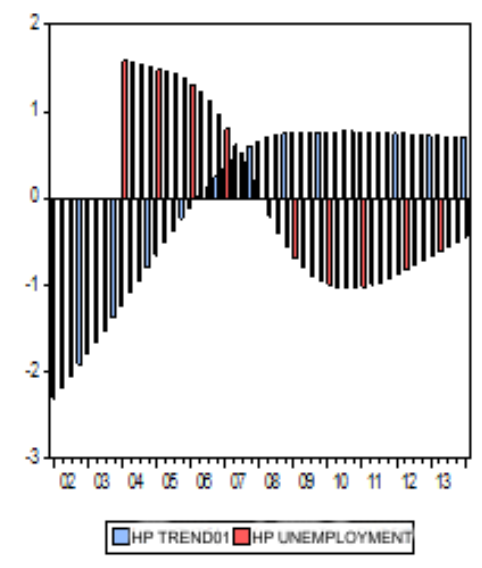

c) The deviation from the trend in personal consumption and the GDP gap

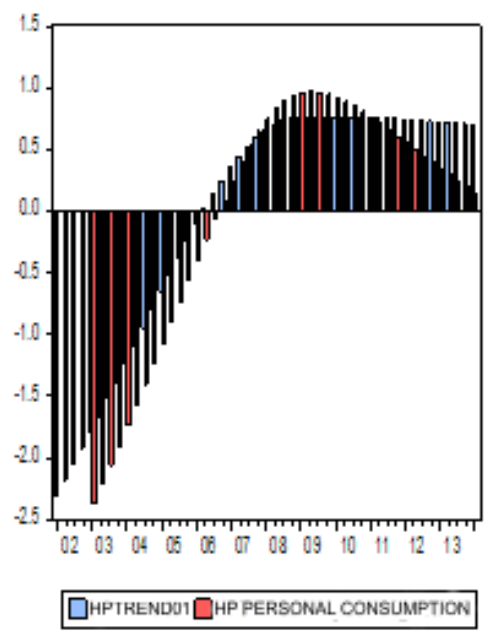

b) The deviation the total sum of salaries of the trend and the GDP gap

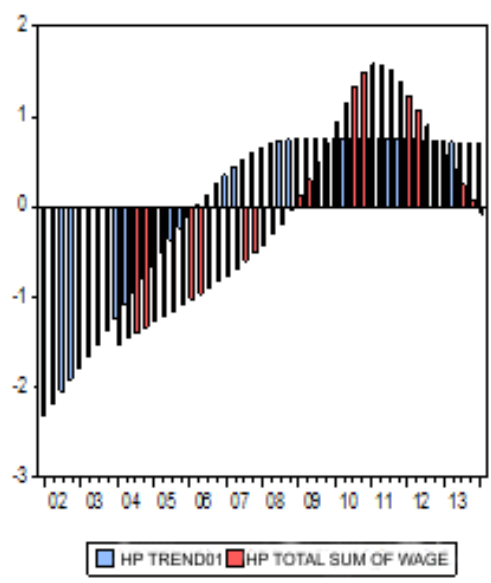

d) The deviation of the gross operating surplus of the trend and the GDP gap

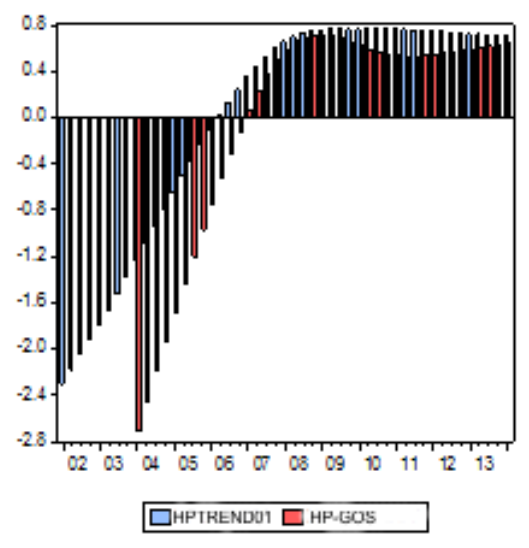

Source: The data for the calculation of macroeconomic bases from the Republic Institute for Statistics. Their trend is the author of the calculation using the HP filter.

Rating elasticity cyclical sensitive elements of budget revenues and expenditures relative to their macroeconomic base is done by econometric. The first econometric testing is necessary to determine the order of integration of individual variables by testing the presence of unit root in all the sensitive elements of the budget cycle and their macroeconomic base. After that, the 
access to the cointegration analysis of the Johansen method was used (Johansen, 2002; Lutkepohl, 2005).

Possible variants after testing co-integration are:

1) series are non-stationary, with unit root, but are not cointegrated. It is necessary to apply a standard analysis of time series such as (unrestricted) VAR model that is applied to the first difference of the observed time series;

2) series are non-stationary, with a unit root and mutually cointegrated in one cointegration relation. In this case is used (limited) VAR model;

3) series are stationary, they have a unit root, and there are more of cointegration relations (Mladenovic \& Nojković, 2009, pp.130-134).

Summary of the results of applying the expanded the Dickey-Fuller unit root test is shown in Table 2. The number corresponds to the number of unit root application process of differentiation in order to come to a time series that is stationary. In addition, this number determines the level of integration of the series. All series are the non-stationary level, that is stationary during the first differential. The table shows that the time series of income taxes, excise taxes, social security contributions, unemployment benefit and wage bill with one unit root, which means they are integrated of order one (mark I (1)). Time series of personal income tax, value added tax, personal consumption, gross operating surplus and employment are fixed in other differential of which is formed by applying the first difference twice. This means that this series with two unit roots and the level of integration of the two rows, I (2)).

Table 2 Summary of results of the expanded the Dickey-Fuller test (ADF)

\begin{tabular}{|c|c|c|c|}
\hline $\begin{array}{c}\text { Cyclically sensitive } \\
\text { elements of the budget } \\
\text { (in current price) }\end{array}$ & $\begin{array}{c}\text { The Level of } \\
\text { integration }\end{array}$ & $\begin{array}{c}\text { Macroeconomic bases } \\
\text { (in current price) }\end{array}$ & $\begin{array}{c}\text { The Level of } \\
\text { integration }\end{array}$ \\
\hline Income tax & I(2) & Wages & I (1) \\
\hline Corporate tax & I(1) & Gross operating surplus & I (2) \\
\hline VAT & I (2) & Personal consumption & I (2) \\
\hline Excise & I (1) & Personal consumption & I (2) \\
\hline $\begin{array}{c}\text { Social security } \\
\text { contributions }\end{array}$ & I (1) & Total sum of wages & I (1) \\
\hline $\begin{array}{c}\text { Unemployment } \\
\text { benefits }\end{array}$ & I (1) & Number of unemployed & I (2) \\
\hline
\end{tabular}

Source: Original data from the database of the Ministry of Finance of the Republic of Serbia. Testing the presence of unit root with the help of Dickey-Fuller's test was carried out by the author. 
The difference between time series with and without unit root has clear economic implications. While the impact of random shocks to the level of stationary time series weakens over time, the effect of shock on the level of time series with unit root has a permanent effect for an indefinite period of time.

The estimated parameters of the integration vectors are needed to construct a short-term error correction model, which has the following form (Bouthevillain et al., 2001):

$\Delta \ln X_{i}=\alpha+\beta\left(\ln X_{t-1}-\gamma \ln V_{t-1}+\varphi+\delta t+\ldots\right)+\delta_{1} \Delta \ln V_{t}+\delta_{2} \Delta \ln V_{t-1}+A+\xi$,

where is $X_{i}$ budget income or expense, expressed in current prices, $V_{i}$ the respective macroeconomic basis, at constant prices, $\alpha$ represents a change in the trend in fiscal relations, $\gamma$ long term elasticity of budget revenues and expenditures, $\beta$ is a parameter of short-term adjustment of budget revenues and expenditures to deviations from the long-term balance and parameters $\delta_{1}$ and $\delta_{2}$ are the short-term elasticity components of the budget in relation to the relevant macroeconomic base in the same period in the previous. The expression within the brackets is called a model error correction. It can include constant $\varphi$ and /or trend $\delta_{t}$, which also stems from the selection of appropriate cointegration vector. A represents a binary (dummy) variables or certain specific characteristics of the economy that are important for the assessment equation.

In the case of cointegration analysis to establish the existence of any cointegration vector, it is estimated the next short-term model (Bouthevillain et al., 2001):

$$
\Delta \ln \mathrm{X}=\alpha+\delta \mathrm{t}+\beta \Delta \ln \mathrm{V}+\mathrm{A}+\xi .
$$

In the case of the tested pairs of individual elements of the state budget and their macroeconomic bases, in addition to a pair of value added tax-personal consumption and excise para-personal consumption, established the existence of a long-term equilibrium relationship, or at least one cointegration vectors using $\lambda$ (trace) statistics. Given that the four pairs of budget components and related macroeconomic bases set up by one cointegration vector for assessing shortterm elasticity of budget components used short-term model is shown by the equation (1). Parameters cointegration vector are needed to calculate the error correction member which is part of the short-term model. In the case of value added tax and personal consumption, as well as excise taxes and personal consumption estimated model shown by Equation (2).

It should be noted that the value of short-term elasticity of budget components relative to their base takes the value of the parameter $\delta_{1}$ from the equation (1). In the event that the estimated coefficient is statistically significant or a sign of deviating from the theoretically expected, coefficient is used in addition to the variable (macro-economic basis) in first differences with a time lag, which is statistically significant and has the expected sign. Short-term 
elasticity of the personal income tax based on the weight of wages, value added tax in relation to the personal consumption of social security contributions in relation to the mass of salaries and benefits for the unemployed relative to the number of unemployed with the values of macroeconomic bases in first differences in the same period, that correspond to the parameter $\delta_{1}$. Economic theory suggests that the growth of macroeconomic bases need to grow and the corresponding budget tax forms or expense. The empirical results of this analysis are interpreted in Table 3, to confirm this. The one-percenters wage increase leads to an increase in tax revenue from the personal income tax by $0.33 \%$ in the short term, while in the long term, to increase $0.16 \%$. The increase in gross operating surplus of $1 \%$ leads to an increase in revenues from taxes on profits of $0.84 \%$ in the short term. Long-term elasticity in the case of income tax is 0.18 , which means that an increase in the tax base by $1 \%$ in the long term increase tax revenues from corporate income tax for $0.18 \%$. Short-term elasticity of the value added tax suggests that one percent increase in personal consumption causes an increase in tax revenues for $0.55 \%$. Since he founded not one cointegration relationship between the value-added tax and personal consumption, there is no long-term relationship between these two variables.

Table 3 Short-term and long-term elasticity of cyclical components sensitive budget of the Republic of Serbia for the period 2005-2014 (first quarter)

\begin{tabular}{|c|c|c|c|c|}
\hline $\begin{array}{c}\text { Cyclically } \\
\text { sensitive elements } \\
\text { of the budget } \\
\text { (in current price) }\end{array}$ & $\begin{array}{l}\text { Macroeconomic } \\
\text { bases } \\
\text { (in current price) }\end{array}$ & $\begin{array}{c}\text { Long-term } \\
\text { elasticity } \\
\text { (cointegration } \\
\text { vector } \delta \text { ) }\end{array}$ & $\begin{array}{c}\text { Parameter } \\
\text { adjustment }(\alpha)\end{array}$ & $\begin{array}{c}\text { Short-term } \\
\text { elasticity }\end{array}$ \\
\hline Income tax & Wages & 0.16 & 1.06 & 0.33 \\
\hline Corporate tax & $\begin{array}{l}\text { Gross operating } \\
\text { surplus (GOS) }\end{array}$ & 0.18 & 2.29 & 0.84 \\
\hline VAT & $\begin{array}{c}\text { Personal } \\
\text { consumption }\end{array}$ & - & 1.8 & 0.55 \\
\hline Excise & $\begin{array}{c}\text { Personal } \\
\text { consumption }\end{array}$ & - & 1.6 & 0.21 \\
\hline $\begin{array}{c}\text { Social security } \\
\text { contributions }\end{array}$ & $\begin{array}{l}\text { Total sum of } \\
\text { wages }\end{array}$ & 0.06 & 0.6 & 0.85 \\
\hline $\begin{array}{l}\text { Unemployment } \\
\text { benefits }\end{array}$ & $\begin{array}{c}\text { Number of } \\
\text { unemployed }\end{array}$ & 0.26 & 0.31 & 0.67 \\
\hline
\end{tabular}

Source: Econometric estimates of the elasticity of the elements of the budget calculated by the authors based on the data of the Ministry of Finance of the Republic of Serbia, the National Bank of Serbia and the Statistical office of the Republic of Serbia.

The same interpretation applies to the excise tax, but the short-term elasticity coefficient is slightly lower $(0.21)$. One-percenters increase in income (wage) affect the growth of social security contributions from the $0.85 \%$ in the short term, ie $0.06 \%$ in the long term. The coefficient of elasticity of unemployment benefits in relation to the number of unemployed suggests that 
the increase in unemployment by $1 \%$ influences the increase in the amount of unemployment benefits from $0.67 \%$ in the short term, ie $0.26 \%$ in the long term.

Only long-term and short-term elasticity and their comparison with earlier estimates for Serbia (Arsić et al., 2013; Fiscal Council, 2012), but also with the EU-15 (Švaljek et al., 2009) is presented in Table 4. Comparison of the estimated short-term elasticity suggesting that they differ from the corresponding estimate elasticities of other authors, and EU-15. The elasticity of the personal income tax in relation to the wage bill, and the elasticity of the value added tax in respect of personal consumption was slightly lower than the average EU-15. Other estimates of the elasticity of budget components relative to their macroeconomic base in the average EU-15. Differences in the estimated coefficient of elasticity incite different methods of calculation which the authors applied. Specifically, this paper used the methods of the European Central Bank (HP filter). Fiscal Council uses the methods OECD (Cobb-Douglas production function). Also in the work by Arsic et al. (2013) used methods OECD, or by using HP filter.

Table 4 Comparison of elasticity of cyclical components sensitive budget of the Republic of Serbia prepared by different methods

\begin{tabular}{|c|c|c|c|c|c|}
\hline $\begin{array}{c}\text { Cyclically } \\
\text { sensitive } \\
\text { elements of the } \\
\text { budget } \\
\text { (in current price) }\end{array}$ & $\begin{array}{c}\text { Macroeconomic } \\
\text { bases } \\
\text { (in current } \\
\text { price) }\end{array}$ & $\begin{array}{c}\text { Serbia } \\
\text { (this } \\
\text { paper) }\end{array}$ & $\begin{array}{c}\text { Serbia } \\
\text { (Fiscal } \\
\text { Council) }\end{array}$ & $\begin{array}{c}\text { Serbia } \\
\text { (Arsi et ol. } \\
\text { 2013) }\end{array}$ & $\begin{array}{c}\text { EU-15 } \\
\text { (min-max) }\end{array}$ \\
\hline Income tax & Wages & 0.33 & 1 & 0.84 & $(1.20-2.60)$ \\
\hline Corporate tax & $\begin{array}{c}\text { Gross operating } \\
\text { surplus (GOS) }\end{array}$ & 0.8 & 1.16 & 1.52 & $(0.72-1.50)$ \\
\hline VAT & $\begin{array}{c}\text { Personal } \\
\text { consumption }\end{array}$ & 0.55 & 1 & 1.05 & $(0.69-1.12)$ \\
\hline Excise & $\begin{array}{c}\text { Personal } \\
\text { consumption }\end{array}$ & 0.21 & $/$ & 1 & $/$ \\
\hline $\begin{array}{c}\text { Social security } \\
\text { contributions }\end{array}$ & $\begin{array}{c}\text { Total sum of } \\
\text { wages }\end{array}$ & 0.85 & 1 & 0.72 & $(0.89-1.00)$ \\
\hline $\begin{array}{c}\text { Unemployment } \\
\text { benefits }\end{array}$ & $\begin{array}{c}\text { Number of } \\
\text { unemployed }\end{array}$ & 0.67 & 1 & 1 & $(0.20-1.07)$ \\
\hline
\end{tabular}

Source: authors; Arsić et al. (2013); Fiscal Council (2012); Švaljek et al. (2009).

The main objective of fiscal policy is that it spontaneously acting countercyclically. When the economy losing momentum, earnings are low, falling company profits and consumption is rather low. This means that the funds collected in taxes are reduced. At the same time, unemployment benefits and other subsidies from the budget increase. In this way, the budget balance deteriorates and fiscal policy automatically becomes expansive. These different effects are called automatic stabilizers of fiscal policy. Automatic stabilizers act 
by themselves. Discretionary fiscal policy is in turn required to be made an explicit decision to amend taxes or public spending. However, such decisions are made and slowly introduced. Once implemented, the decisions in the context of fiscal policy tend exercising more rapid impact on the economy (6-12 months) monetary policy (12-24 months). Due to the automatic stabilizers, budget figures do not reveal what the government is doing with its fiscal policy. The budget must be changed for two reasons. It can, for example, to improve because the government is cutting public spending or increase taxes or because the economy is in a state of rapid economic development. To distinguish between these two factors, it is useful to analyze the cyclically adjusted budgets.

Calculating cyclical fiscal deficit and score the character of fiscal policy in the Republic of Serbia was carried out using the method of the European Central Bank during the smoothing parameter $\lambda=300$, using the HP filter. The procedure is based on the concept of self GDP. Let $b^{c}$ means the cyclical component of the budget balance as a percentage of GDP, $R$ denotes public revenues and $S$ public spending, $R^{*} / R=\left(Y^{*} / Y\right)^{\rho}$ and $S^{*} / S=\left(Y^{*} / Y\right)^{\eta}, \rho$ and $\eta$ is elasticity $R$ and $S$ in relation to the macroeconomic base, $\left(Y_{t}-Y_{t}^{*}\right) / Y_{t}^{*}$ represents the output gap (Carnot et al., 2011, p. 207):

$$
b_{t}^{c}=\left(\rho R_{t} / Y_{t}-\eta S_{t} / Y_{t}\right)\left(Y_{t}-Y_{t}^{*}\right) / Y_{t}^{*}
$$

$R$ and $S$ can be defined as the total public revenues and public expenditures, or limited to a part that is sensitive to the production cycle. In the latter case, the separate components of $R$ and $S$, which are not considered to be cyclically sensitive, will be included in the structural balance. ${ }^{1}$

The cyclically adjusted budget balance is an estimate of what would be the balance in a given year if the output gap is zero. The actual budget balance is lower than the cyclically adjusted budget balance when GDP is below its potential, i.e. when the output gap is negative and vice versa when the output gap is positive. The difference between the actual and the cyclically adjusted budget balance is the result of automatic stabilizers (Baldwin \& Wyplosz, 2010, p. 523).

The following figure illustrates the comparison of actual and cyclically adjusted fiscal deficit from the previous analysis, in relation to the GDP gap.

\footnotetext{
${ }^{1}$ Based on the current average elasticity in the member countries of the OECD, the cyclical component of the budget can be roughly estimated as $(R / Y+1 / 4 \mathrm{~S} / \mathrm{Y})$. Production gap or $b_{c}^{t}=y_{\text {gap }} \cdot \eta$, where $\eta$ denotes the sensitivity of the fiscal balance I is equal to the difference between the elasticity of tax revenue and public expenditure. With an average size of government from around $40 \%$ of GDP, this means that, according to the golden rule, bc is about half of the output gap.
} 
Figure 3 Actual and cyclically adjusted budget of the Republic of Serbia, from 2007 to 2014 (first quarter)

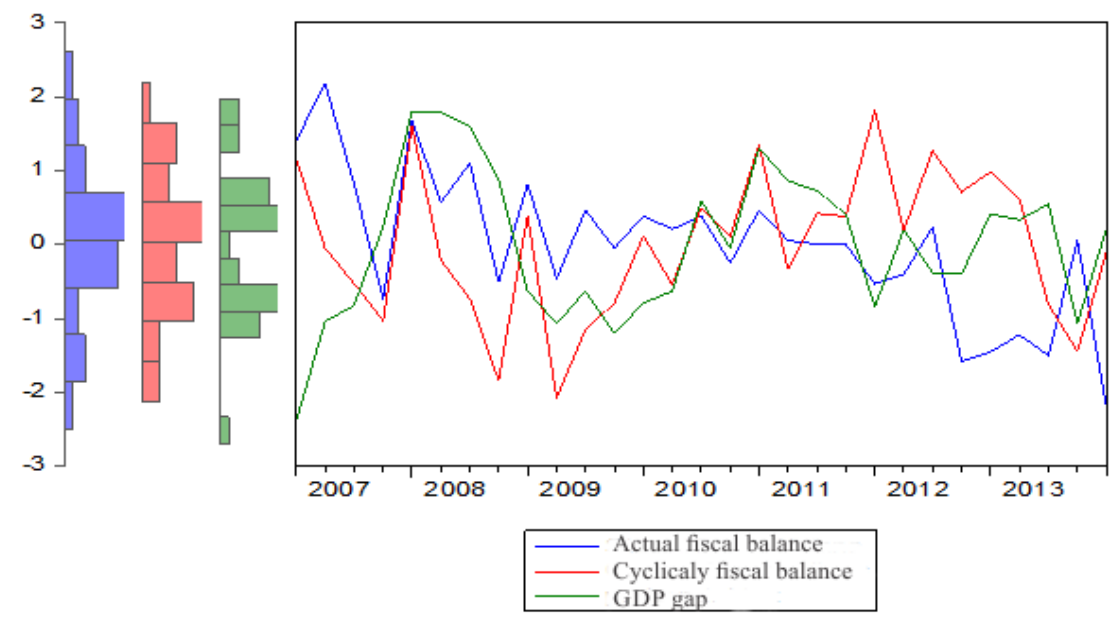

Note: All variables are measured as percentage of GDP.

Source: data from the actual fiscal balance and GDP are from the database of the Ministry of Finance, the cyclically adjusted deficit and the GDP gap is calculated by the author. Graphical interpretation was done by the author.Napomena: sve varijable su merene kao procenat BDP-a.

Figure 3 reveals that the actual balance in the Republic of Serbia is mostly moving along with self GDP, indicating that automatic stabilizers operate. It should be noted that the actual fiscal balance over the gap of GDP by the fourth quarter of 2008, which means that at that time the economy was expanding and had positive GDP gap. A slight improvement in the fiscal balance is noticeable from the fourth quarter of 2010, when we started with measures of fiscal consolidation. However, since 2012, again fiscal balance has deteriorated. This suggests that GDP was below its potential, and the output gap is negative, which is consistent with expectations that the crisis increases the fiscal deficit. The cyclically adjusted budget, which is a measure of discretionary actions, tends in the same direction of movement as well as the GDP gap. It shows that the government in good years, when the GDP gap was growing, implemented a restrictive fiscal policy, while its expansionary policy in a situation where the GDP gap was decreasing. However, a careful examination of the figures indicates the exceptions in the Republic of Serbia. In the pre-crisis period, until 2008, the Government of the Republic of Serbia led pro-cyclical fiscal policy in an already overheated economy, achieving the fiscal deficit instead of a surplus. A similar situation exists in the fourth quarter of 2009, second quarter of 2010 and in the period between 2012 and 2013 because the fiscal policy response is not expansive, but due to limited fiscal space in the Republic of Serbia, even 
restrictive. Since 2013, fiscal policy has forced countercyclical movement, which alleviates the effects of the economic cycle.

\section{Evaluation of the Fiscal position of the Republic of Serbia on the Basis of the Structural Fiscal Deficit}

To estimate the structural fiscal balance different econometric method is used, which can produce different results on the same data in a given time period ${ }^{2}$. Arithmetic, $b^{\text {struc }}$ denotes the structural fiscal balance, $b_{t}$ budget balance, $b^{c}$ cyclical component of the budget balance, as a percentage of GDP:

$$
b^{\text {struc }}=b_{t}-b_{t}^{c} .
$$

Estimate cyclically-adjusted and structural fiscal deficit refers to the period from the first quarter of 2007 to the first quarter of 2014. The analysis is based on quarterly data, because the number of annual data is insufficient for econometric estimates. Although this is a relatively short period of time, there is a significant problem to compare data in most of the analyzed time series, and, in some cases, there is a problem of reliability. So, in some cases, the adjustment to the official data to improve their comparability was necessary, while in other cases it was not possible (in these cases were used dummy variables (Eng. Dummy) to isolate the impact of methodological changes). Structural fiscal deficit is obtained as the difference between the actual level of income and expense and the cyclical part of public revenues and expenditures (which are calculated in the previous section). Structural fiscal deficit reflects the size of the fiscal deficit independent of the business cycle. For the calculation of the structural fiscal deficit primary deficit of the consolidated state is commonly used, not the consolidated deficit of the state because it considers the expenses for interest are not the result of current fiscal policy.

The empirical results thus obtained structural results for the Republic of Serbia are given in the first column of Table 5 in the context of comparison with the results of other authors. The Government of the Republic of Serbia during the expansion that preceded the current crisis, has achieved high economic growth and high external deficits that temporarily generate high public revenues. These revenues are interpreted as permanent, resulting in the adoption of legislation that is permanently increases public spending and reduced some taxes. Despite the high public revenue, the actual fiscal deficit in Serbia in the period 2006-2008 was relatively low, suggesting that the government takes an expansive fiscal policy. However, the structural fiscal deficit in this period in the Republic of Serbia is already very high, which indicates the need to tighten fiscal policy. During this period, the state should achieve a surplus and

\footnotetext{
${ }^{2}$ Prescribing mandatory methods for the evaluation of the structural fiscal deficit at the EU level can be partially solved the problem of using different methodologies.
} 
accumulate reserves for "hard times." The systematic increase in public spending and the reduction of certain taxes at the beginning of the crisis in late 2008 led to a strong and lasting growth of the fiscal deficit and the rapid growth of public debt. In the past few years, in the Republic of Serbia recorded a structural fiscal deficit of over 4\% of GDP per year (in 2012 a record 5.6\% of GDP), which led to a rapid and significant growth of public debt to a level of $63.5 \%$ of GDP at the end of the first quarter of 2014, threatening to jeopardize the sustainability of public finances.

Table 5 Comparison of results of estimate of the structural balance by various authors for the Republic of Serbia, as a\% of GDP in the period 2008 - 2013

\begin{tabular}{|c|c|c|c|}
\hline Year & $\begin{array}{c}\text { Structural deficit } \\
\text { (this paper) }\end{array}$ & $\begin{array}{c}\text { Structural deficit } \\
\text { (Arsić et al., 2013) }\end{array}$ & $\begin{array}{c}\text { Structural deficit } \\
\text { (IMF) }\end{array}$ \\
\hline 2008. & -2.3 & -4.7 & -4.1 \\
\hline 2009. & -4.3 & -3.9 & -4.1 \\
\hline 2010. & -4.6 & -4.1 & -4.4 \\
\hline 2011. & -4.7 & -4.6 & -5.3 \\
\hline 2012. & -5.6 & $/$ & -5.8 \\
\hline 2013. & -4.1 & $/$ & -5.5 \\
\hline
\end{tabular}

Sorce: Authors; Arsić et al., 2013; IMF Word Economic Outlook, April 2014.

Figure 4 Actual and structural fiscal balance in the Republic of Serbia, in the period from 2007 to 2014 (first quarter), as a\% of GDP

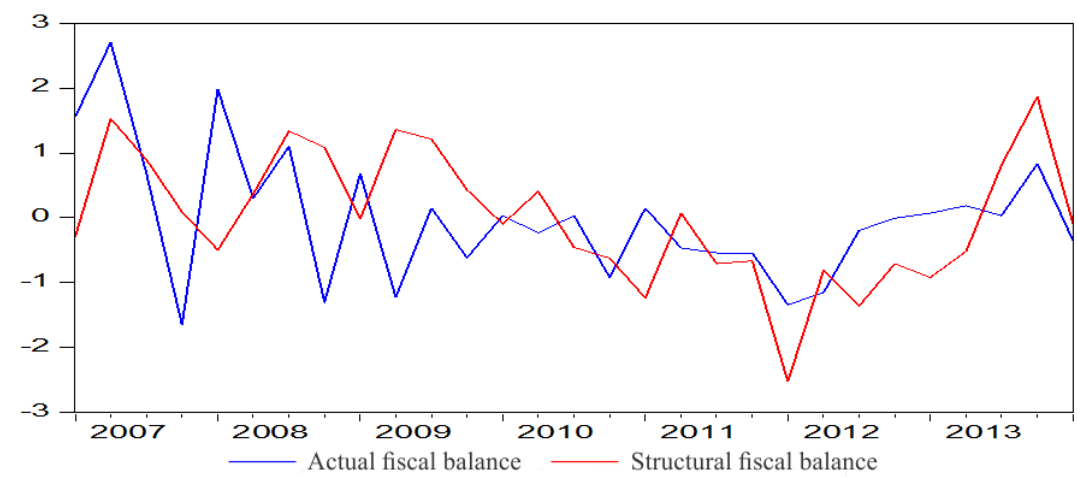

Source: primary data on the components of the structural deficit taken from the Ministry of Finance, calculation and graphical display of the structural deficit having committed the authors.

Comparison of actual and structural deficit shown in Figure 4 can be concluded that the structural fiscal deficit was relatively close to the actual deficit. The conclusion suggests that: (1) automatic stabilizers generally played a more prominent role than consistent countercyclical discretionary fiscal policy, and (2) changes in discretionary fiscal policy were late or were not well targeted (related to the other factors, not the stabilization of GDP). 


\section{Conclusion}

For the assessment of the fiscal position of the Republic of Serbia in real circumstances the authors used cyclically-adjusted deficit, structural deficit and the primary balance.

The cyclically adjusted budget, which is a measure of discretionary actions, tends in the same direction of movement as well as the GDP gap. This shows that during an economic expansion, when the GDP gap is growing, the government implements a restrictive fiscal policy, while its expansionary policy in a situation where the GDP gap is decreasing. However, the econometric analysis shows that only since 2013, the fiscal policy in the Republic of Serbia tends toward countercyclical movement, which relieves the effects of the economic cycle.

The estimated structural deficit in the Republic of Serbia (4.1\% of GDP) suggests that the actual deficit heavily influenced by systemic factors that relate to the operation of automatic stabilizer. This means that the fiscal deficit in the Republic of Serbia will not be automatically will be eliminated from the economic recovery, but discretionary fiscal policy is necessary in order to reduce public expenditure and raising revenue. Since the structural fiscal deficit reflects the impact of long-term macroeconomic trends, it is necessary to promptly adopt economic policy measures in order to prevent their impact on the growth of the fiscal deficit.

\section{References}

Arsić, M., Nojković A. \& Ranđelović S. (2013). Would economic recovery imply fiscal stabilization in Serbia? Ekonomika preduzeca, 2013 (3-4), 222-238.

Baldwin, R. \& Wyplosz, Ch. (2010). Ekonomija evropskih integracija. Beograd: Datastatus.

Bouthevillain, C., Cour-Thimann, C., van de Dool, G., Hernandez de Cos, P., Langenus, G., Mohr, M., Momigliano, S. \& Tujula, M. (2001). Cyclically adjusted budget balances: an alternative approach (Working Paper Series 007), Frankfurt: European Central Bank.

Carnot N., Koen V. \& Tissot B. (2011). Economic Forecasting and Policy. New York: Palgrave Macmillan.

Hodrick, R. J. \& Prescott E. (1997). Postwar U.S. Business Cycles: An Empirical Investigation. Journal of Money, Credit and Banking, Vol. 29 (1), 1-16.

Fatas A. \& Mihov I. (2008). Fiscal Policy and Business Cycles: An Empirical Investigation, http://faculty.insead.edu/fatas/myc.pdf, Accessed 15 August 2012.

Johansen, S. (2002). A small sample correction for the test of cointegration rank in the vector autoregressive model. Econometrica, 70, 1929-1961.

Lutkepohl, H. (2005). New Introduction to Mutiple Time Series Analysis. Berlin: SpringerVerlag.

Mladenović, Z. \& Nojković, A. (2005). Analiza vremenskih serija: primeri iz srpske privrede. Beograd: Ekonomski fakultet.

Perotti, R. (2007). Fiscal Policy in Developing Countries: A Framework and Some Questions (Policy Research Working Paper 4365), Washington: World Bank. 
Švaljek S., Vizek M. \& Mervar A. (2009). Ciklički prilagođeni proračunski saldo: primer Hrvatske. Privredna kretanja i ekonmska politika, 120/2009,49-81.

Todorović-Đurović J. \& Đorđević M. (2010). Javne finansije. Niš: Ekonomski fakultet.

\section{EMPIRIJSKA OCENA FISKALNE POZICIJE REPUBLIKE SRBIJE}

Apstrakt: U ovom radu se ocenjuje veličina ciklične i strukturne komponente fiskalnog deficita Republike Srbije za period od prvog kvartala 2002. godine do drugog kvartala 2014. godine. Korišćena je metoda Evropske centralne banke, gde je pretpostavljeno da su ciklički osetljivi elementi državnog budžeta porez na dohodak, porez na dobit, porez na dodatu na vrednost, akcize, doprinosi za socijalno osiguranje i naknade za nezaposlene. Elastičnost ciklički osetljivih elemenata u odnosu na njihove makroekonomske osnovice su ocenjene VEC modelom sa korekcijom odstupanja. Rezultati sugerišu da su automatski stabilizatori, generalno više odigrali ulogu nego dosledna kontraciklična diskreciona fiskalna politika, što znači da su diskrecione mere bile neblagovremene ili nisu bile dobro usmerene.

Ključne reči: ciklični deficit, strukturni deficit, BDP.

\section{Authors' biographies}

Jadranka Đurović Todorović has been a full professor at the Faculty of Economics, University of Niš since 2012. Her fields of enterest are monetary economics and public finance. She teaches at all three levels of study. She is a winner of the Silver sign of University of Niš, as the best graduate student in 1992 and and the October Award of the City of Leskovac for Finance in 2015. She is a reviewer in numerous journals and author of 4 books and 3 monographies. She has been a participant of many domestic and international projects in field of economics and she is the author of more than 140 scientific articles published in domestic and international journals and thematic collections of papers from international and domestic scientific conferences.

Marija Vuković, maiden name Vlahovic, is a lecturer at the Higher School of Professional Studies in Novi Sad, specilising in the scientific field of Finance. She teaches International Taxation and Financial Strategies and Tax Planning. Her work focuses on the analysis of the level of fiscal deficit and exploring possibilities for its financing; the design of the tax system in terms of equity and efficiency; design of adequate and responsible policy of public spending; encouraging healthy fiscal decentralization; optimisation level of borrowing by the central and local authorities and finding alternative borrowing options. Marija Vukovic is interested in gendersensitised approach to these issues. 